\title{
WTO Export Restriction of Agricultural Commodities and Its Impacts for G-33 Members
}

\author{
Steven Raja Ingot \\ Trade Analysis and Development Agency \\ Ministry of Trade, Republic of Indonesia \\ Jakarta, Indonesia \\ sri.bako@gmail.com \\ Arie Mardiansyah \\ Trade Analysis and Development Agency \\ Ministry of Trade, Republic of Indonesia \\ Jakarta, Indonesia \\ arie.mardiansyah@yahoo.com
}

\author{
Dian V.Panjaitan \\ Department of Economics, Faculty of Economics and \\ Management \\ $I P B$ University \\ Bogor, Indonesia \\ fadhian@yahoo.co.id \\ Leo M. Christoffel \\ Trade Analysis and Development Agency \\ Ministry of Trade. Republic of Indonesia \\ Jakarta, Indonesia \\ leochristoffel@gmail.com
}

\begin{abstract}
The discussion of agricultural Export Restriction (ER) at the World Trade Organization (WTO), which is a mechanism to temporarily stop the export of agricultural product that aims to prevent food shortages in exporting countries has been intensively negotiated. However, as a net importer of agricultural products and the member of G33 countries, Indonesia should address the ER policy because it may have potential to increase prices and threaten food security in domestic market and G33 member countries. This study uses a descriptive qualitative statistical analysis to determine Import Dependency Ratio (IDR) and SelfSufficiency Ratio (SSR) for five main imported agricultural products by G33 countries such as rice, corn, soybean, wheat, and horticulture. The Computable General Equilibrium (CGE) Analysis using GTAP ver.9 is also used to analyze the potential impact of agricultural product export restrictions for five analyzed products on macroeconomic and sectoral indicators. Based on IDR and SSR it can be concluded that almost all G33 countries heavily rely on wheat imports, as many as 36 countries depend on imported wheat with IDR values varying between $70 \%$ - $215 \%$. On the other hand, several G-33 countries have a fairly good level of fulfillment of consumption from domestic production (SSR) or more than $80 \%$. Moreover, based on the GTAP calculation on the Indonesia case, export restrictions will have a negative macroeconomic impact on Indonesia. However, in sectoral perspective Indonesian farmers/producers can take advantage of the impact of the export restriction policy as an opportunity to increase their production.
\end{abstract}

Keywords-export restriction, CGE, self sufficiency, import dependency

\section{INTRODUCTION}

The discussion of the agricultural issue at the Committee on Agriculture (CoA) WTO has been discussed intensely in preparation toward the $12^{\text {th }}$ WTO Ministerial Conference that to be held in Kazakhstan in year 2020. One important issue that will be negotiated and agreed upon is Export Restriction (ER). In accordance to Article XI paragraph 2 (a) GATT WTO regarding the General Elimination of Quantitative Restrictions, the ER is a mechanism for terminating exports in a term that aims to alleviate or prevent food shortages in exporting countries. Based on article 12 of the Agreement on Agriculture (AoA) concerning Disciplines on Export Prohibitions and Restrictions that countries implementing ER are required to submit notifications with ER-1 form consisting of product descriptions, Harmonized System (HS) numbers, justification for implementation and duration of implementation.

Recently there were two proposals emerge regarding the ER issue in WTO, first from Singapore as of document number WTO JOB/AG/148 and the Japanese et. al. as of document number WTO JOB/AG/149 [34] and WTO $\mathrm{JOB} / \mathrm{AG} / 156$ [35]. As one of the initiators on the formation of the State Group 33 (G-33) in agricultural product trade negotiations in the WTO, Indonesia needs to take into its consideration that the ER may take negative impact to secure food security interest in G-33 domestic market. G-33 by itself is a group of countries that fight for food security, poverty alleviation and rural development in every discussion on agricultural issues in WTO.

In global agricultural trade there are only few countries in the world that dominate total export of agricultural products, as shown in Table 1 [2]. These countries are also the main exporting agricultural products to the G33 members. The policy of ER that is not implemented properly by exporting countries may have a negative impact for food supply and food prices globally, especially to G-33 members.

TABLE I. MAJOR EXPORTING COUNTRIES AND MARKET SHARE

\begin{tabular}{|l|l|c|}
\hline \multicolumn{1}{|c|}{ Commodity } & \multicolumn{1}{|c|}{ Major Exporting Countries } & $\begin{array}{c}\text { Market } \\
\text { Share }\end{array}$ \\
\hline Wheat & $\begin{array}{l}\text { EU, Russian Federation, US, } \\
\text { Canada, Australia }\end{array}$ & $74 \%$ \\
\hline Rice & $\begin{array}{l}\text { India, Thailand, Viet Nam, Pakistan, } \\
\text { US }\end{array}$ & $82 \%$ \\
\hline Corn & $\begin{array}{l}\text { US, Brazil, Argentina, Ukraine, } \\
\text { Russian Federation }\end{array}$ & $90 \%$ \\
\hline Soybean & $\begin{array}{l}\text { Brazil, US, Paraguay, Canada, } \\
\text { Argentina }\end{array}$ & $96 \%$ \\
\hline
\end{tabular}

The objectives of this study are (1) to determine the level of dependence on major food commodity imports and (2) 
analyze the impact of the implementation of ER policies on Indonesia's macro and sectoral economies and G33 member countries. This is expected to provide input to the Indonesian government and members of the G-33 in addressing and determining the steps in the ER negotiations at the WTO.

\section{Methodology}

Descriptive qualitative statistical analysis is used to determine IDR and SSR for five imported main agricultural products by G33 countries such as Rice, Corn, Soybean, Wheat, and Horticulture. Because there is no research about the measure of IDR and SSR that is generally appropriate for a country, the IDR critical point is determined at $20 \%$ as a limit for the dependence level of a country on an imported product. Meanwhile, the critical point of the SSR is $80 \%$ as a limit for the level of a country's ability to meet its consumption from domestic production. Then, CGE Analysis with GTAP ver.9 is applied to analyze the impact of agricultural product export restrictions on macroeconomic and sectoral indicators in the case example in Indonesia [3] and [5].

\section{A. Import Dependency Ratio (IDR)}

The IDR is defined as: IDR = imports $\mathrm{x} 100 /$ (production + imports - exports). The complement of this ratio to 100 would represent that part of the domestic food supply that has been produced in the country itself. Or in other words, if a country has an ability to meet their domestic consumption by domestic supply the IDR would be zero (0\%) [9].

\section{B. Self-sufficiency Ratio (SSR)}

The SSR is defined as: $\mathrm{SSR}=$ production $\mathrm{x}$ 100/(production + imports - exports) [9]. The SSR can be calculated for individual commodities, groups of commodities of similar nutritional values and, after appropriate conversion of the commodity equations, also for the aggregate of all commodities. In the context of food security, the SSR is often taken to indicate the extent to which a country relies on its own production resources, i.e. the higher the ratio the greater the self-sufficiency.

While the SSR can be the appropriate tool when assessing the supply situation for individual commodities, a certain degree of caution should be observed when looking at the overall food situation. In the case, however, where a large part of a country's production of one commodity, e.g. other cereals, is exported, the SSR may be very high but the country may still have to rely heavily on imports of food commodities to feed the population. The self-sufficiency rate (as defined above) cannot be the complement to 100 of the import dependency rate or vice versa.

\section{Computable General Equilibrium (CGE)}

Computable General Equilibrium (CGE) using Global Trade Analysis Project version 9 (GTAP-v9) which is static comparative, multi-region and multi-sectoral is used to analyze the impact of agricultural product export restrictions on macroeconomic and sectoral indicators [5] and [8] in Indonesia through a scenario or simulation of decline the export volume of major agricultural / food products from partner countries to $\mathrm{G} 33$ member countries is $100 \%$.

Exporting countries are United States of America (USA), European Union (EU 28), Canada, and Australia (Table 1). The country is an exporter of agricultural food commodities to all G33 member countries. However, in the GTAP database not all G33 member countries are available. Of the 43 G33 members, only 31 countries are available in the GTAP database. So that country aggregation is as follows:

TABLE II. COUNTRY AGGREGATION

\begin{tabular}{|c|c|c|}
\hline No & Code & Description \\
\hline 1 & AUS & Australia \\
\hline 2 & CAN & Canada \\
\hline 3 & EU & European Union 28 \\
\hline 4 & IDN & Indonesia \\
\hline 5 & UA & United States of America \\
\hline 6 & G33 & $\begin{array}{l}\text { Members of G33: China, Mongolia, Lao PDR, } \\
\text { Philippines, India, Pakistan, } \\
\text { Sri Lanka, Peru, Venezuela, Guatemala, } \\
\text { Honduras, Nicaragua, Panama, El Salvador, } \\
\text { Dominican Republic, Jamaica, Trinidad and } \\
\text { Tobago, Turkey, Benin, Cote d'Ivoire, Nigeria, } \\
\text { Senegal, Kenya, Madagascar, Mauritius, } \\
\text { Mozambique, Tanzania, Uganda, Zambia, } \\
\text { Zimbabwe. }\end{array}$ \\
\hline 6 & VIET & Vietnam \\
\hline 7 & RUSSIA & Russia Federation \\
\hline 8 & IND & India \\
\hline 9 & THAI & Thailand \\
\hline 10 & ROW & Others Rest of The World \\
\hline
\end{tabular}

While for product sector aggregation are as follows:

TABLE III. SECTORAL AGgREGATION

\begin{tabular}{|c|c|}
\hline Sector & Code \\
\hline Cereal grains nec & CORN \\
\hline Wheat & WHEAT \\
\hline Paddy rice, Processed rice & RICE \\
\hline Oil seeds & SOYBEAN \\
\hline Vegetables, fruit, nuts & VEGFRUIT \\
\hline $\begin{array}{l}\text { Sugar cane, sugar beet, Plant-based fibers, } \\
\text { Crops nec }\end{array}$ & Grains and Crops \\
\hline $\begin{array}{l}\text { Petroleum, coal products, } \\
\text { Chemical,rubber,plastic prods, Mineral } \\
\text { products nec, Ferrous metals, Metals nec, } \\
\text { Electronic equipment, Machinery and } \\
\text { equipment nec }\end{array}$ & Heavy Manufacturing \\
\hline $\begin{array}{l}\text { Leather products, Wood products, Paper } \\
\text { products, publishing, Metal products, } \\
\text { Motor vehicles and parts, Transport } \\
\text { equipment nec, Manufactures nec }\end{array}$ & Light Manufacturing \\
\hline $\begin{array}{l}\text { Cattle,sheep,goats,horses, Animal } \\
\text { products nec, Raw milk, Wool, silk-worm } \\
\text { cocoons, Meat: cattle,sheep,goats,horse, } \\
\text { Meat products nec }\end{array}$ & Livestock and Meat Products \\
\hline $\begin{array}{l}\text { Forestry, Fishing, coal, oil, gas, minerals } \\
\text { nec }\end{array}$ & Mining and Extraction \\
\hline $\begin{array}{l}\text { Financial services nec, Insurance, } \\
\text { Business services nec, Recreation and } \\
\text { other services, } \\
\text { PubAdmin/Defence/Health/Educat, }\end{array}$ & Other Services \\
\hline
\end{tabular}




\begin{tabular}{|l|l|}
\hline \multicolumn{1}{|c|}{ Sector } & \multicolumn{1}{c|}{ Code } \\
\hline Dwellings & Processed Food \\
\hline $\begin{array}{l}\text { Vegetable oils and fats, Dairy products, } \\
\text { Sugar, Food products nec, Beverages and } \\
\text { tobacco products }\end{array}$ & Textiles and Clothing \\
\hline Textiles, Wearing apparel & Transport and \\
\hline $\begin{array}{l}\text { Trade, Transport nec, Sea transport, Air } \\
\text { transport, Communication, Electricity, } \\
\text { Gas manufacture, distribution, Water, } \\
\text { Construction }\end{array}$ & Communication \\
\hline
\end{tabular}

\section{RESULT AND DISCUSSION}

\section{A. Result of IDR and SSR}

Based on data from the Food and Agriculture of the United Nations, many G-33 countries have a level of import dependence (IDR) of more than $20 \%$ to meet the consumption of their main food products (Figure 1). Out of 42 members of G-33 there are 29 countries still depend on Rice imports, 20 countries still depend on Corn imports, and 15 countries still depend on Soybean imports, and 16 countries still depend on Horticulture imports. It should be noted that almost all G33 countries rely heavily on Wheat imports. As many as 36 countries depend on imported Wheat with IDR values varying between $70 \%-215 \%$.

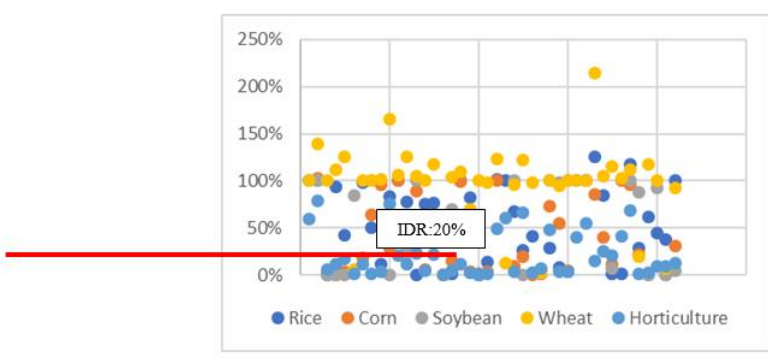

Fig. 1. Import Dependency Ratio G-33 Economy

Source: FAO, 2013; (author calculation)

On the other hand, some G-33 Economy have a fairly good level of fulfillment of consumption from domestic production (SSR) / more than $80 \%$ (Figure 2). Horticulture is a food product with SSR that is relatively good compared to other food products, even some countries have a production surplus and become net exporters with SSR values $>100 \%$, such as Guatemala (194\%), Honduras (184\%), Suriname $(148 \%)$, etc. Whereas, Wheat is a food product with the lowest SSR where almost all countries are unable to produce and must depend on imported food products, except Zambia (155\%), India (108\%), Pakistan (102\%), and Turkey (101\%).

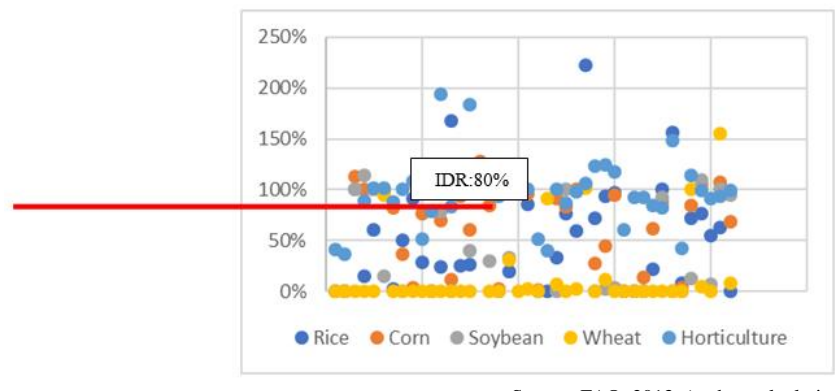

Fig. 2. Self-Sufficiency Ratio G-33 Countries

\section{B. Result of CGE Analysis}

The ER policy reduce the welfare level of Indonesia and other G33 economy, reduce the volume of imports and consumption. In addition, the simulation also show that real GDP will be negatively affected. However, in macro, the ER policy will have a positive effect on Indonesia's total or aggregate export volume by $2.85 \%$.

Sectorally, in terms of demand, the ER policy will reduce total household demand originating from imports, while household demand for domestic products tends to increase. This because the increase in import prices is far higher than the prices in the domestic market so that domestic products are more competitive than imported products.

Furthermore, the ER policy will also cause increasing of prices, both import prices and prices at the level of domestic consumption. However, the increasing of import prices is higher than the increasing price at a level of domestic consumption so the supply of imported products will be reduced and replaced by supply of domestic products, except for Wheat. This condition can be an opportunity for domestic farmers/ producers to increase production, because even though domestic prices rise, demand continues to rise. In addition, the increasing of price will also provide price incentives for farmers to produce more, because prices are relatively higher than before implementation of ER.

In terms of output, the ER policy will decrease the number of outputs, either of imported products or domestic products for export. However, the declining of imports is far greater than the amount of exports, except for Wheat, because Indonesia does not produce and export Wheat.

\section{CONCLUSION AND POLICY RECOMMENDATION}

\section{A. Conclusions}

Based on analysis, Indonesia still rely on imported Wheat and Soybean to fulfil its main food product consumption. On the other hand, many G-33 countries also have a high level of import dependence on some food products which Wheat is a food product with the highest IDR value relative to other food products. The ER policy will potentially cause difficulties for Indonesia and the G-33 countries to fulfill their main food product needs in order to meet domestic consumption and food security interest in each country.

Furthermore, result of CGE calculation shows that the ER policy will bring a negative macroeconomic impact on Indonesia. Sectorally, the ER policy will also cause negative impact on demand, price, and output. However, Indonesian farmers/ producers could take advantage of the impact of the ER policy as an opportunity to increase their production to meet demand at domestic market as a result of the declining demand of imported food products domestically.

\section{B. Policy Recommendations}

Indonesia, together with the G-33 countries, needs to make careful decisions because the adoption of the ER policy can threaten the fulfilment of domestic consumption and food security interest in each country. Because of the potential problems that arise from the ER policy, Indonesia and the G-33 must emphasize in the WTO negotiations that there is a need for mechanisms and procedures, including parameters and indicators, of the ER implementation that can balance the interests of exporting countries and importing 
countries, and can be generally accepted by all WTO member countries. In addition, ER implementation must also be based on member compliance and transparency concepts so that the ER implementation needs to be equipped with a monitoring and evaluation mechanism both in terms of periodic implementation and its rules of the game.

Moreover, to anticipate the implementation of ER policies by exporting countries, the Indonesian government needs to encourage increasing of agricultural production and maintaining supply stability domestically. It aims to reduce the dependence of Indonesia on imported food products, especially Wheat and Soybean. In this study the authors also provide space for researchers and analysts to conduct further research related to the critical point of a country's dependence on an imported food product (IDR) and the level of a country's ability to meet its consumption of domestic production (SSR) which can be adjusted to conditions in each country. In Indonesia, it is necessary to review the stock limits for import decision making because stabilization of domestic stocks is important to maintain price stability.

\section{REFERENCES}

[1] Bouët and Laborde, "Economics of Export Taxation in a Context of Food risis A Theoretical and CGE Approach Contribution", IFPRI Discussion Paper, 00994, 2010.

[2] [BPS] Badan Pusat Statistik, http://www.bps.go.id. 2016.

[3] Brockmeier, M., "A Graphical Exposition of GTAP Model”, GTAP Technical Paper No. 8, Centre for Global Trade Analysis, Purde University, 1996.

[4] CNN, "Jumlah Lahan Berkurang, Produksi Padi Tahun Lalu Merosot". Retrieved February 11, 2019 from https://www.cnnindonesia.com/ekonomi/20150302151819-9236104/jumlah-lahan-berkurang-produksi-padi-tahun-lalu-merosot/.

[5] Christian and Pearson, "Implementing Quotas in GTAP using GEMPACK or How to Linearize an Inequality", GTAP Technical Paper No. 4, 1996.

[6] Devarajan S., Go D., Schiff M. "The Whys and Why Nots of Export Taxation". Policy Research Working Paper WPS 1684, Economics Division, The Vol. 7, pp. 187-198, 2005.

[7] Elbehri.A, Leetmaa.S. "How Significant Are Export Subsidies to Agricultural Trade? Trade and Welfare Implications of Global Reforms", Paper presented at the Annual Meetings of the American Agricultural Economics Association, 2002.

[8] Estrades, Manuel and Guillermo, "The Role Of Export Restrictions In Agricultural Trade", This paper is a preliminary version of an IATRC Commissioned Paper, prepared for 2016 GTAP Conference.

[9] [FAO] Food and Agriculture Organization, http://www.fao.org/statistics/en/. 2019. 